\title{
RUNX2 Gene
}

National Cancer Institute

\section{Source}

National Cancer Institute. RUNX2 Gene. NCI Thesaurus. Code C91785.

This gene plays a role in both transcription and cell differentiation. 